\title{
Findings From International Surveys Providing a Snapshot of the State of KM From a Practitioner Point of View
}

\author{
Nicholas J Milton
}

\begin{abstract}
Data collected through an online survey and through a number of detailed company assessments throw light on the relative strengths and weaknesses of different elements of Knowledge Management (KM) frameworks as applied globally. The online survey a quick self-administered test, shows the strongest elements within the framework to be Technology and Behaviors and Culture. The weakest elements are KM Governance and KM Roles. The assessment - a detailed diagnostic process based on in-depth interviews, shows the strongest elements within the framework to be Technology and the Discussion of Knowledge. The weakest elements are KM Governance and KM Roles. a comparison of the results from the two sources is reassuringly close. More data may allow a more detailed analysis. Preliminary results suggest that national culture may influence the development of Knowledge Management Frameworks, with a correlation between strong Individuality and weak KM Governance and Roles.

Keywords: Knowledge Management Survey, Knowledge Management Assessment, Knowledge Management Benchmark, Knowledge Management Framework, Knowledge Management Roles, Knowledge Management Technology, Knowledge Management Governance
\end{abstract}

\section{Introduction}

Research, albeit often unstructured, is part and parcel of the knowledge management practitioner's life, particularly for knowledge management consultants. Every engagement with a client is an experiment and a data point. The consultant is constantly looking for evidence and information on approaches to knowledge management, successful and unsuccessful alike. He or she needs to know what succeeds in knowledge management terms and what fails, in order to be able to transfer that knowledge to future clients. An effective knowledge management consultancy that has operated successfully for many years therefore has built up a body of empirical knowledge which may be extremely useful. 
Seldom is that knowledge shared. It is treated as competitive advantage: guarded by secrecy and non disclosure agreements. Also, unlike academic research, there may be no hypothesis to be tested, and no consistent data set to be interrogated. The dataset remains empirical and unstructured.

The case study presented in this chapter is an example of data and experience collected over a number of years, but is unusual in having been built around systematic data collection from a number of clients. One of the services that the author's company provides to organizations is an assessment and benchmarking service. This is provided in two forms: a free online selfbenchmark survey, and a detailed interview-based analysis the organizational frameworks applied to knowledge management. Enough data have been collected now from these two forms of survey to draw some tentative conclusions about strengths and weaknesses in knowledge management.

This is not an academic study, but an empirical study based on practical experience, presented in a descriptive way. The study includes no literature survey, no research methodology, and no statistical testing. The results should therefore be taken as empirical results; hopefully interesting for practitioners and serving as an insight to researchers.

\section{Survey methods}

Survey data on the completeness of organizational knowledge management frameworks has been collected in two ways.

Firstly, a number of on-line knowledge management surveys are available at http://www.knoco.com.au/surveys/. One of these is a survey of knowledge management maturity, which looks at the development levels of several of the key components of a knowledge management framework. Participants were invited to take part in the survey through messages on Linked-In, and through a regular Knowledge Management newsletter sent to a sign-up mailing list of over 3000 people. Data were collected over the period from December 2012 to March 2104.

The survey rates $\mathrm{KM}$ maturity against 10 elements, assigning marks from 1 to 5 as participants select one from a number of statements for describing different maturity or development levels. The 10 elements are listed below, and the five statements for each element which describe the maturity levels are shown in Table 1:

- Learning Before

- Learning During

- Learning After

- Communities of practice (CoPs)

- Ownership of Knowledge (k ownership) 
- KM roles

- KM technologies

- Behavior and culture

- Governance

- Business alignment

In addition to the maturity data, the survey also records the geography and the industry segment of the organization which the respondent is describing. To date, 248 responses to this survey have been received over a period of 16 months.

Secondly, the author's company has, for the past decade, offered an assessment service for clients. This is a detailed diagnostic assessment of the current status of the knowledge management framework within the client organization, which allows it to be benchmarked against knowledge management peers. Currently we have assessment data from over 50 assessments, each one representing an organization, or a team, department or division within an organization. Each of these assessments is covered by confidentiality agreements, so the name of the companies involved, the results of individual surveys or comments from interviewed staff cannot be published.

The Assessment model is based on assessing the effectiveness of the flow of knowledge from one person, team, department or project to another, and the assessment framework is a combination of two basic Knowledge Management models:

1) a model derived from the SECI model of Nonaka and Takeuchi (1995), which considers the four transitions of knowledge:

- The transfer of knowledge from tacit to tacit states, through Discussion

- The transfer of knowledge from tacit or explicit state, through Capture

- The transfer and refinement of knowledge within the explicit state, through Synthesis

- The transfer of knowledge from explicit to tacit state, through access and re-use.

2) a model of four enablers for knowledge management:

People (roles and accountabilities)

Processes

Technology

Governance, including clarity of expectation, performance management and support. 


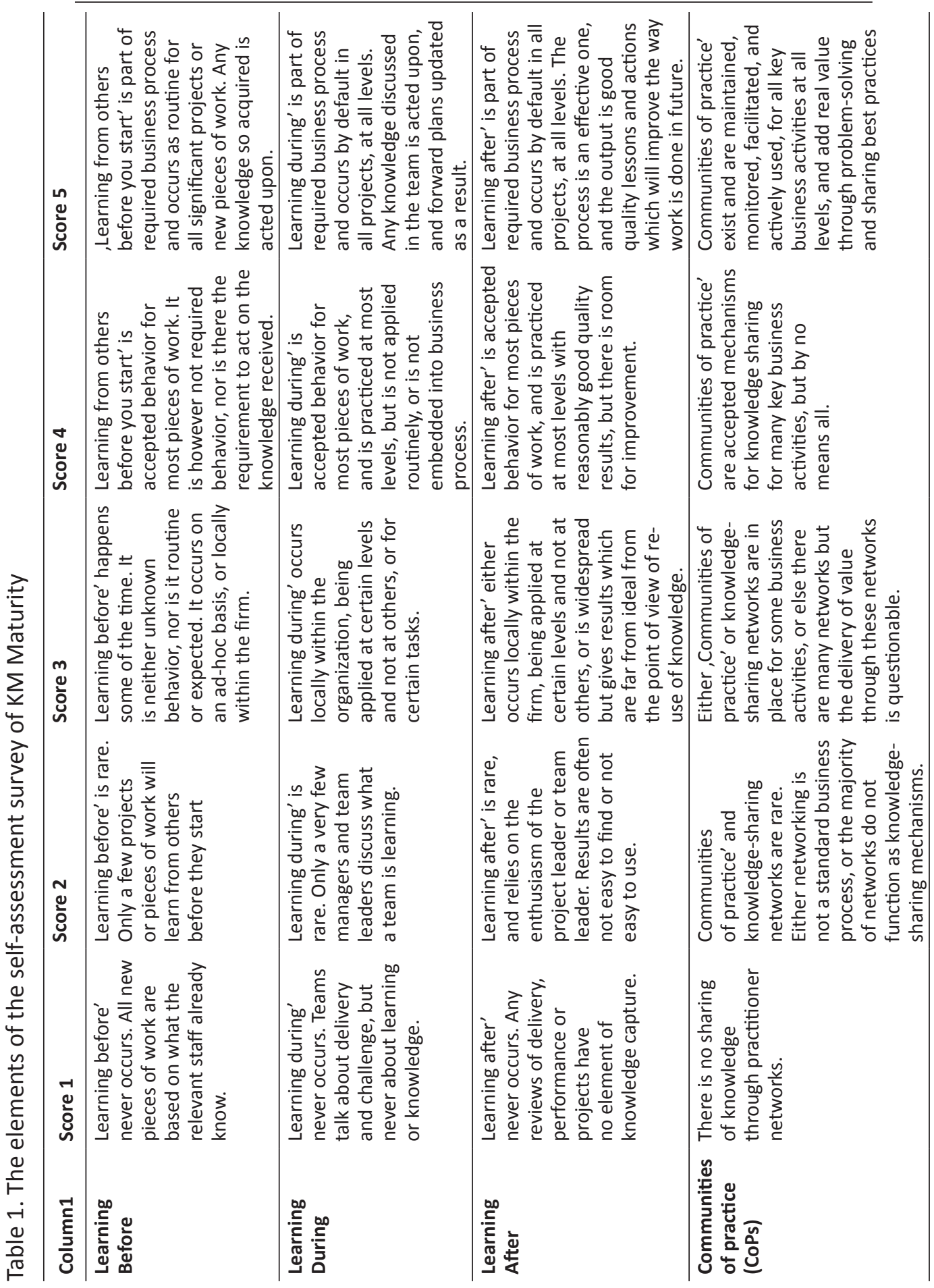

Knowledge Management Special Issue: Connecting Theory and Practice, Patrick Lambe (Ed.) 


\begin{tabular}{|c|c|c|}
\hline 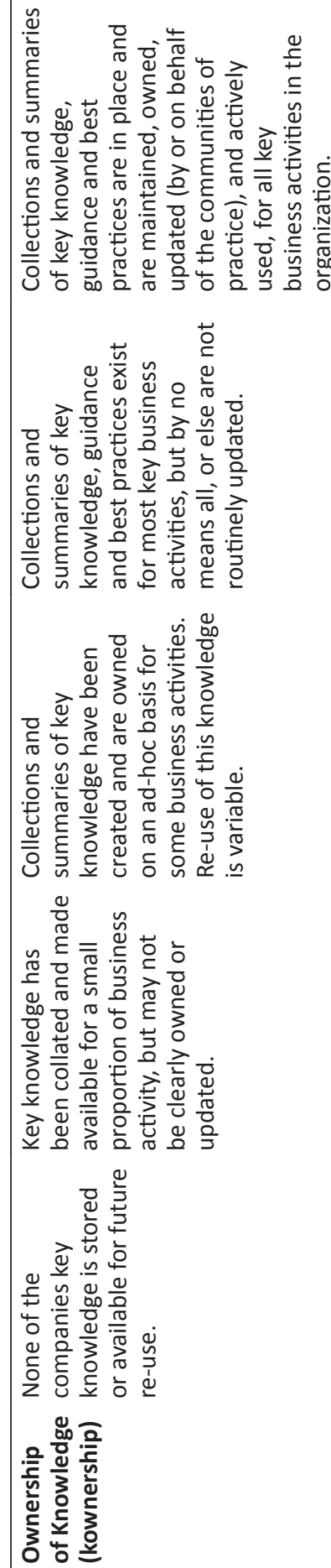 & 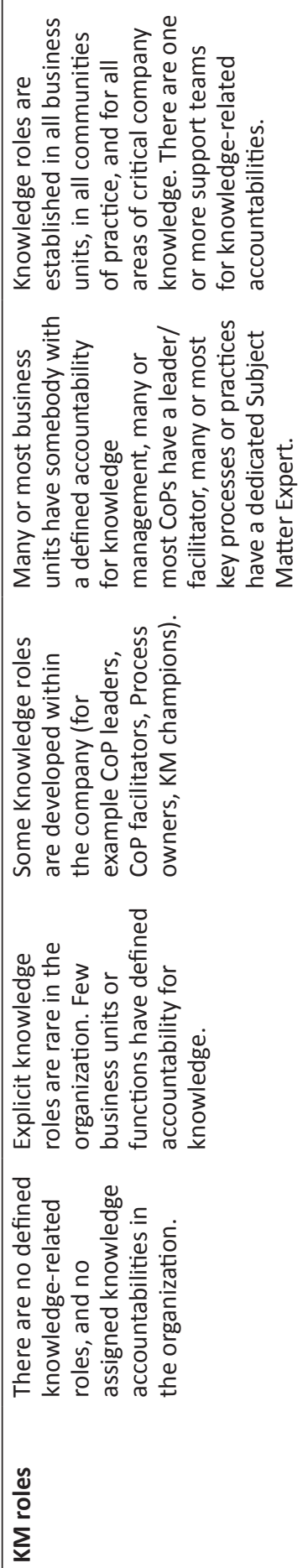 & 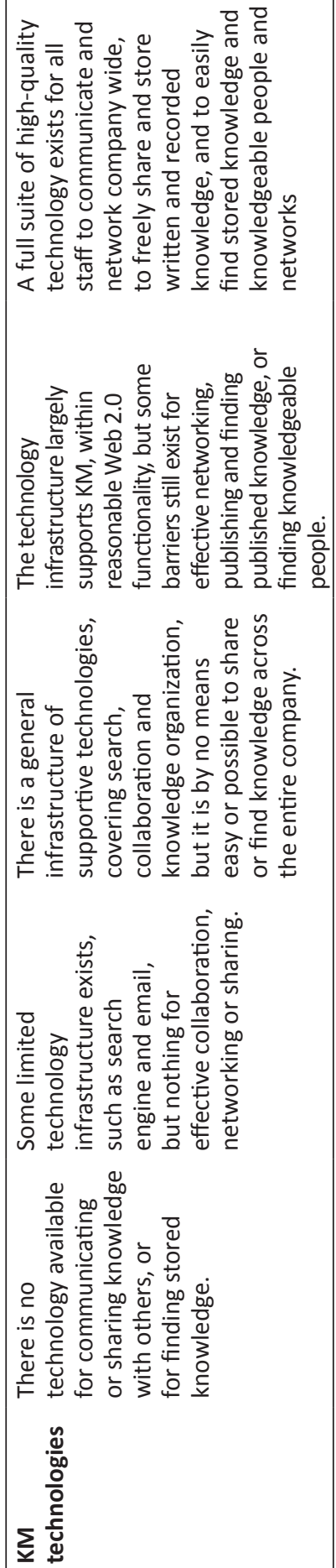 \\
\hline
\end{tabular}




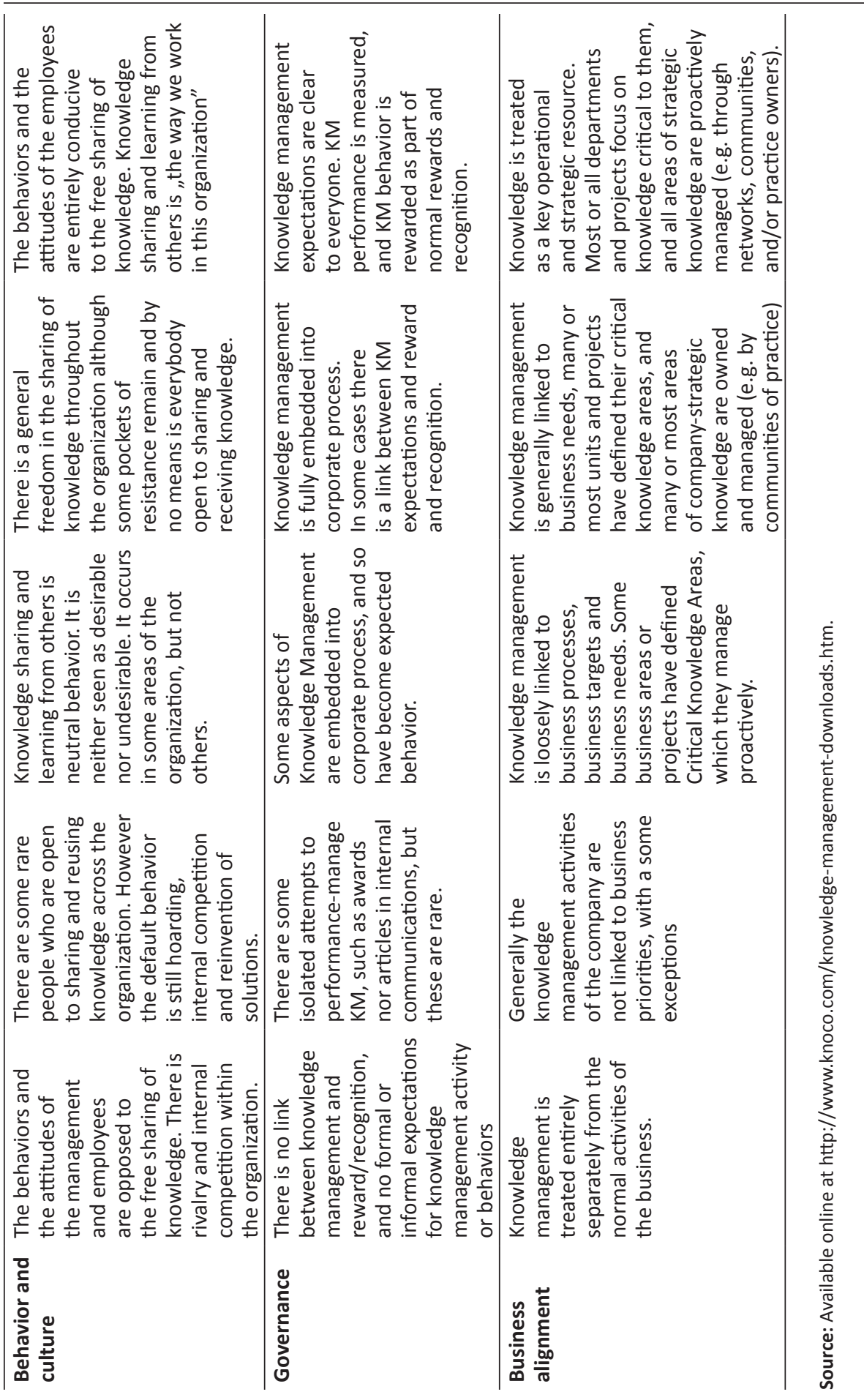

Knowledge Management Special Issue: Connecting Theory and Practice, Patrick Lambe (Ed.) 
The effectiveness and completeness of the Knowledge Management framework and the client organizations is therefore measured against 15 elements, shown in Figure 1:

\begin{tabular}{|l|l|l|l|l|}
\hline & Discuss & Capture & Synthesise & $\begin{array}{l}\text { Access and } \\
\text { re-use }\end{array}$ \\
\hline Roles & $\begin{array}{l}\text { Roles for managing and } \\
\text { facilitating discussion of } \\
\text { knowledge }\end{array}$ & $\begin{array}{l}\text { Roles for ensuring and } \\
\text { facilitating capture of } \\
\text { knowledge }\end{array}$ & $\begin{array}{l}\text { Roles for knowledge } \\
\text { synthesis }\end{array}$ & $\begin{array}{l}\text { Roles for ensuring and } \\
\text { access and re-use of } \\
\text { knowledge }\end{array}$ \\
\hline Processes & $\begin{array}{l}\text { Processes for } \\
\text { discussion of } \\
\text { knowledge }\end{array}$ & $\begin{array}{l}\text { Processes for capturing } \\
\text { knowledge }\end{array}$ & $\begin{array}{l}\text { Processes for } \\
\text { synthesising knowledge }\end{array}$ & $\begin{array}{l}\text { Processes for access } \\
\text { and re-use of } \\
\text { knowledge }\end{array}$ \\
\hline Technology & $\begin{array}{l}\text { Technologies to enable } \\
\text { discussion of } \\
\text { knowledge }\end{array}$ & $\begin{array}{l}\text { Technologies to enable } \\
\text { capture of knowledge }\end{array}$ & $\begin{array}{l}\text { Technologies to enable } \\
\text { synthesis of knowledge }\end{array}$ & $\begin{array}{l}\text { Technologies to enable } \\
\text { access and re-use of } \\
\text { knowledge }\end{array}$ \\
\hline Governance & $\begin{array}{l}\text { Clear expectations for } \\
\text { knowledge management activity }\end{array}$ & $\begin{array}{l}\text { Performance management of } \\
\text { knowledge management activity }\end{array}$ & $\begin{array}{l}\text { Support for knowledge } \\
\text { management activity }\end{array}$ \\
\hline
\end{tabular}

Figure 1. Fifteen elements for KM Assessment Source

The presence and performance of each of these elements within the client organizations is determined through structured in-depth diagnostic interviews of a range of staff. The interviews, which last approximately an hour, take each interviewee through open and closed questions around culture, people, process and technology facets of $\mathrm{KM}$, using a standard protocol. The interview may be performed face-to-face, or by telephone if face-to-face is impossible.

The current status of each of the 15 points as described in each interview is given a mark out of 5 , depending on the level of completeness of that element, as follows:

1) this element is completely absent or ineffective,

2) this element is slightly addressed,

3) this element is partly present with significant room for improvement,

4) this element is largely present with some room for improvement,

5) this element is fully in place.

The results of the assessment are reported back to the client, together with a comparison against the best in class, and a list of all of the possible interventions to complete the clients knowledge management framework. By "best in class" we mean organizations with a long history in Knowledge Management, a published record in delivering business results through Knowledge Management, and consistent recognition in schemes such as the Most Admired Knowledge Enterprise awards ${ }^{1}$. In addition to this clienttailored report, the number of repeat assessments allows a comparison across multiple organizations to look at patterns of poorly developed and well developed Knowledge management elements.

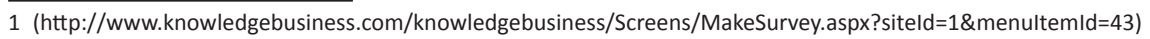




\section{Analysis and study}

The following results from the survey and from the assessment are presented for discussion. The demographics of the online survey participants are presented below in Tables 1 and 2. Please note, the survey allows participants to describe themselves as researchers (people who are visiting the survey out of interest, rather than to benchmark their organization), though providing a tick-box labeled "I am a KM Consultant / Student/ Researcher and the results should NOT be used in Benchmarking". These results have been removed from the dataset described in Tables 1 and 2 and shown in Figures 2, 3 and 7, leaving 149 responses which are believed to represent reliable data.

Table 2. Country demographics for respondents to the online survey

\begin{tabular}{|c|c|}
\hline Country & Number of responses \\
\hline Algeria & 1 \\
\hline American Samoa & 1 \\
\hline Angola & 1 \\
\hline Argentina & 2 \\
\hline Australia & 22 \\
\hline Azerbaijan & 4 \\
\hline Belgium & 12 \\
\hline Canada & 9 \\
\hline Chile & 1 \\
\hline China & 3 \\
\hline Denmark & 4 \\
\hline Ethiopia & 1 \\
\hline France & 3 \\
\hline Germany & 1 \\
\hline India & 4 \\
\hline Indonesia & 1 \\
\hline Jordan & 1 \\
\hline Kuwait & 1 \\
\hline Latvia & 1 \\
\hline Luxembourg & 1 \\
\hline Malaysia & 3 \\
\hline New Zealand & 1 \\
\hline Norway & 1 \\
\hline Portugal & 1 \\
\hline Saudi Arabia & 1 \\
\hline South Africa & 4 \\
\hline Sweden & 5 \\
\hline Switzerland & 1 \\
\hline Thailand & 1 \\
\hline UAE & 2 \\
\hline UK & 18 \\
\hline US & 23 \\
\hline Multinational or unknown & 13 \\
\hline
\end{tabular}


Table 3. Industry demographics for respondents to the online survey

\begin{tabular}{lc}
\hline Industry sector & Number of responses \\
\hline Agriculture, forestry and fishing & 5 \\
Construction & 5 \\
Education and Training & 11 \\
Electricity, Water and Waste & 8 \\
Financial and Insurance Services & 9 \\
Health care and social assistance & 4 \\
Information, media and telecoms & 10 \\
Manufacturing & 5 \\
Mining, oil and gas & 32 \\
Other services & 9 \\
Professional, scientific and technical & 24 \\
Public administration and safety - defense & 15 \\
Retail trade & 1 \\
Transport, postal and warehousing & 1 \\
Multi-industry or unknown & 10 \\
\hline
\end{tabular}

The average scores (between 1 and 5) for the different elements of Knowledge Management measured by the online survey are shown in Figure 2 , where 5 is a high level of maturity, and 1 is a low level.

The following observations can be made:

- Average scores are moderate to low. Although some individual responses include scores as high as 5 for some elements, and some scores as low as 1 , the data-set taken as a whole suggests that Knowledge Management is not yet a fully mature discipline.

- The highest score is for Technology, by a significant margin.

- The second highest score is for culture and behaviors. Culture, long considered to be the biggest barrier to Knowledge Management, no longer seems to be the biggest issue.

- The lowest score, by a very long way, is for Governance.

- The second lowest is for Roles. 


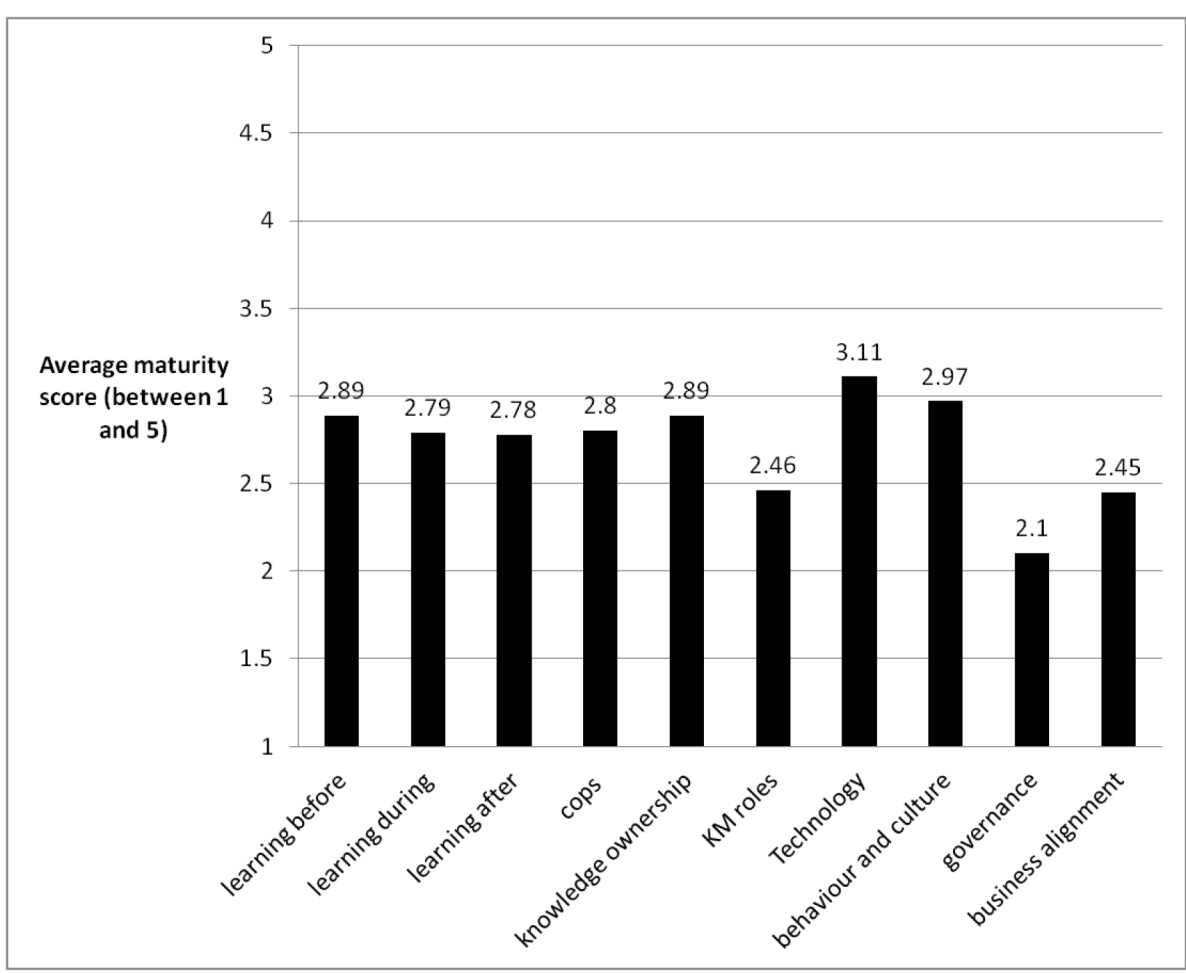

Figure 2. Average results for the ten elements of the online survey

Figure 3 shows the results for six countries - those 7 where we have 5 or more entries to the survey/ The overall KM Maturity scores for these countries are in the following order, from highest to lowest:

- Belgium

- Sweden

- Australia

- Canada

- USA

- UK

All 6 countries see the same dip on the graph related to KM governance and business alignment, and USA, Canada and Australia see a similar dip on $\mathrm{KM}$ roles. 


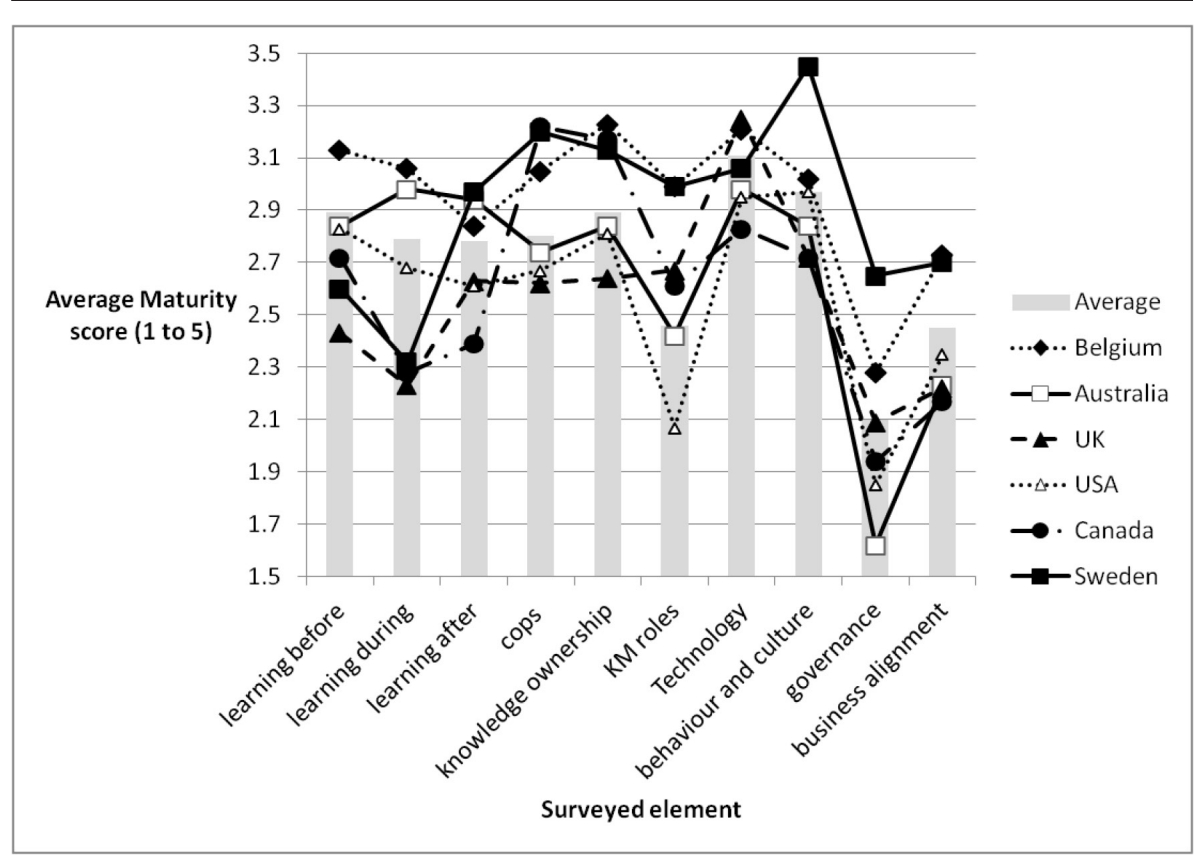

Figure 3. Survey results for 6 countries

The demographics for the Assessment are shown below in Tables 4 and 5.

Table 4. Country demographics for sample sets for the Assessment

\begin{tabular}{lc}
\hline Country & $\begin{array}{c}\text { Number of Assessments with the country } \\
\text { sample set }\end{array}$ \\
\hline Angola & 1 \\
Argentina & 1 \\
Australia & 2 \\
Azerbaijan & 4 \\
Belgium & 2 \\
Brazil & 1 \\
Canada & 1 \\
Chile & 1 \\
Kuwait & 1 \\
Malaysia & 1 \\
Norway & 1 \\
Oman & 1 \\
Saudi Arabia & 1 \\
South Africa & 2 \\
Sweden & 5 \\
Thailand & 1 \\
UAE & 2 \\
UK & 10 \\
US & 2 \\
Multinational & 18
\end{tabular}


Table 5. Industry demographics for sample sets for the Assessment

\begin{tabular}{lc}
\hline Industry sector & Number of responses \\
\hline Construction & 2 \\
Education and Training & 1 \\
Electricity, Water and Waste & 2 \\
Financial and Insurance Services & 1 \\
Manufacturing & 9 \\
Mining, oil and gas & 30 \\
Professional, scientific and technical & 1 \\
Public administration and safety - defense & 6 \\
\hline
\end{tabular}

The average results for the 15 components of Knowledge Management measured by the Assessments are shown in Figure 4.

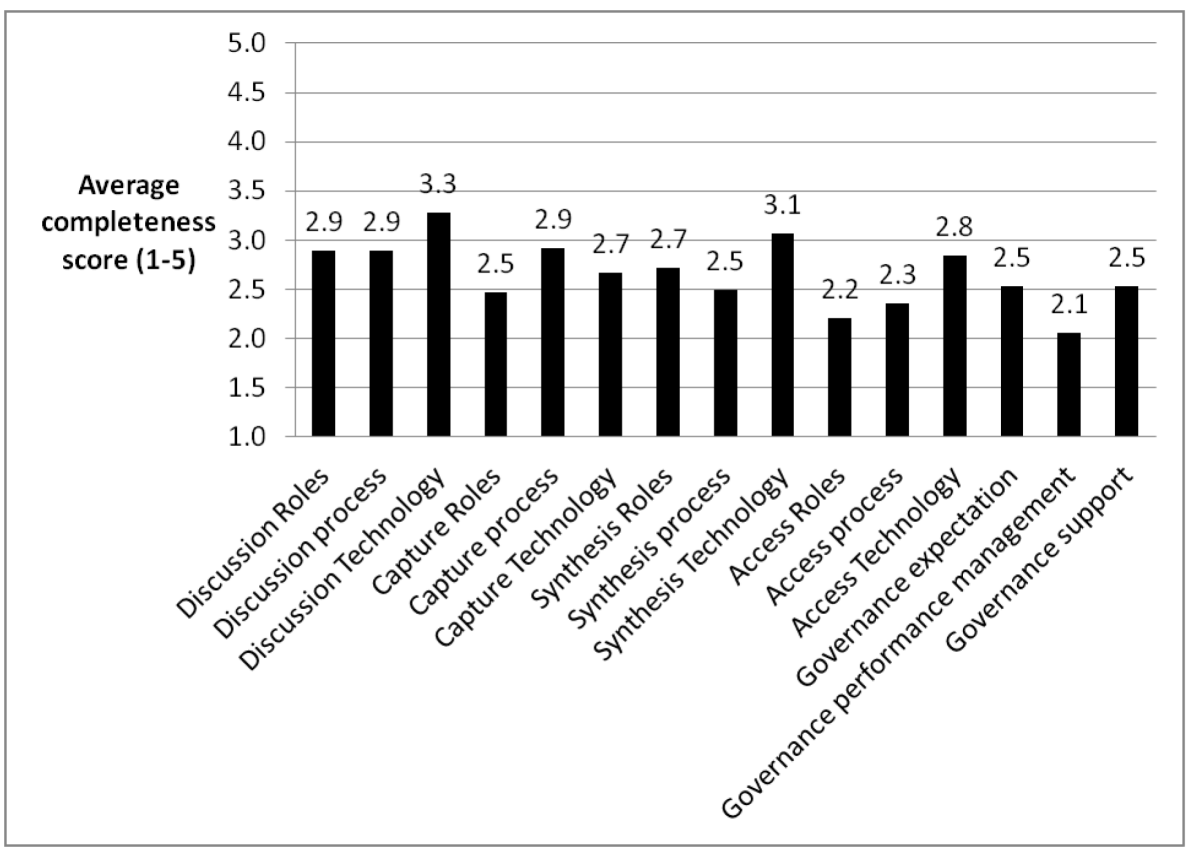

Figure 4. Average results for the fifteen elements of the assessment

The following observations can be made:

- As previously, the average scores are moderate to low. Although some individual responses include scores as high as 5 for some elements, and some scores as low as 1 , the data-set taken as a whole suggests that Knowledge Management is not yet a mature discipline.

- The highest scores are for Discussion Technology and Synthesis Technology. 
- The lowest score is for the Performance Management element of Governance.

These 15 elements can be grouped into the four transitions of knowledge described above as based on the four quadrants of the SECI model, and also into the four enablers mentioned above. The results of these groupings are shown in Figures 5 and 6.

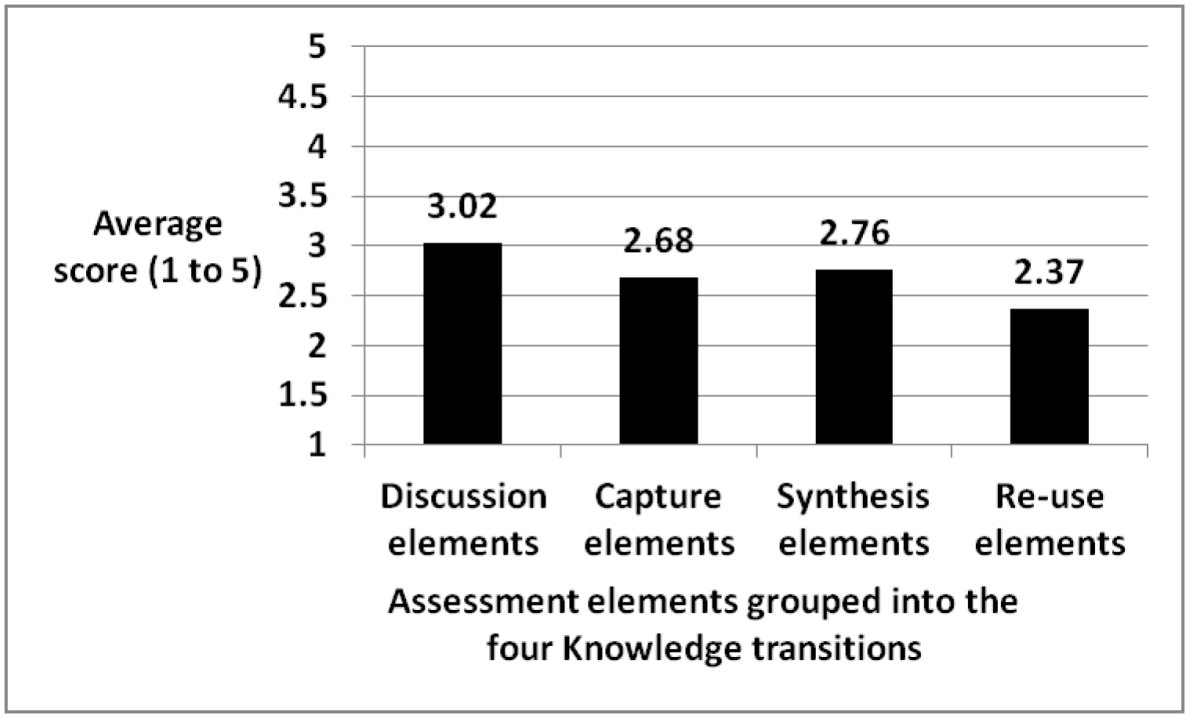

Figure 5. Average results for the fifteen elements of the assessment

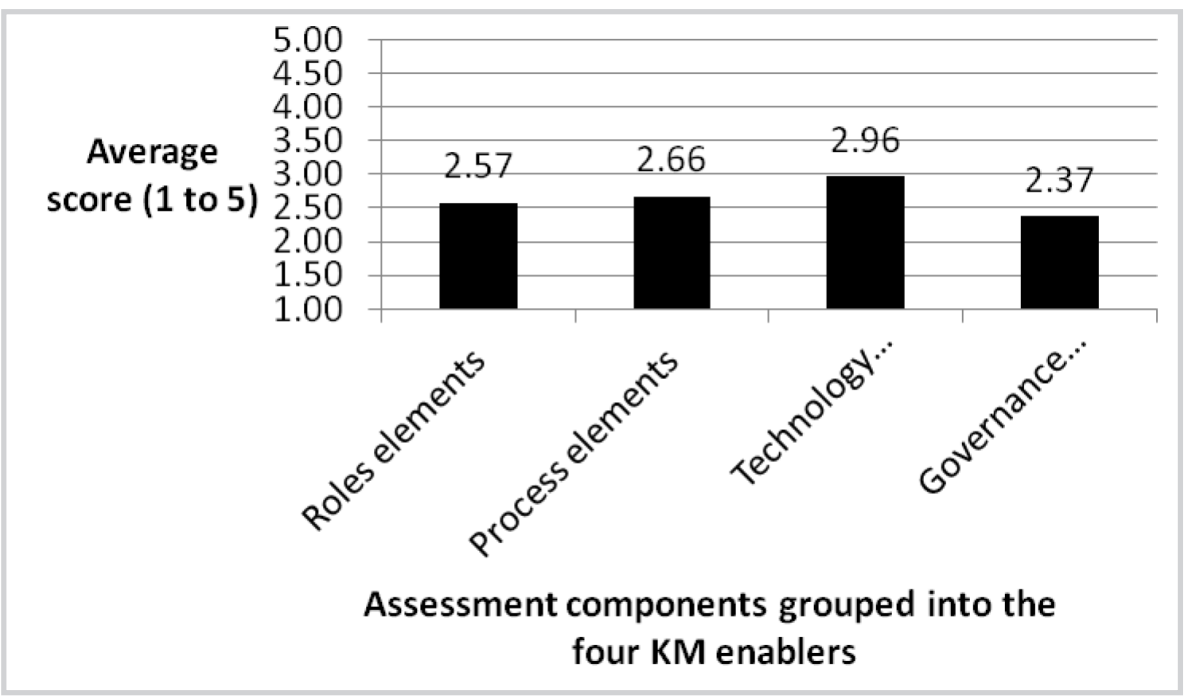

Figure 6. Average results for the fifteen elements of the assessment 
These figures illustrate two more points;

- The discussion transition (tacit to tacit) is on average the strongest, with roles, technologies and processes most often in place. The weakest transition is knowledge Access and re-use (explicit to tacit).

- The Technology enabler is the strongest of the four, with Governance being the weakest and Roles the second weakest.

There is some equivalence in content between the Online Survey and the Assessment, as shown in table 6 below.

Table 6. Equivalence of Assessment components and Survey elements

\begin{tabular}{lc}
\hline Assessment Component & Survey element \\
\hline Discussion Roles & CoPs \\
Discussion process & CoPs \\
Discussion Technology & Technology \\
Capture Roles & KM roles \\
Capture process & Learning After \\
Capture Technology & Technology \\
Synthesis Roles & Knowledge Ownership \\
Synthesis process & \\
Synthesis Technology & Technology \\
Access Roles & KM Roles \\
Access process & Learning Before \\
Access Technology & Technology \\
Governance expectation & \\
Governance performance management & Governance \\
Governance support & \\
\hline
\end{tabular}

This equivalence therefore allows data from the two datasets to be directly compared, as shown in Figure 7 below. 


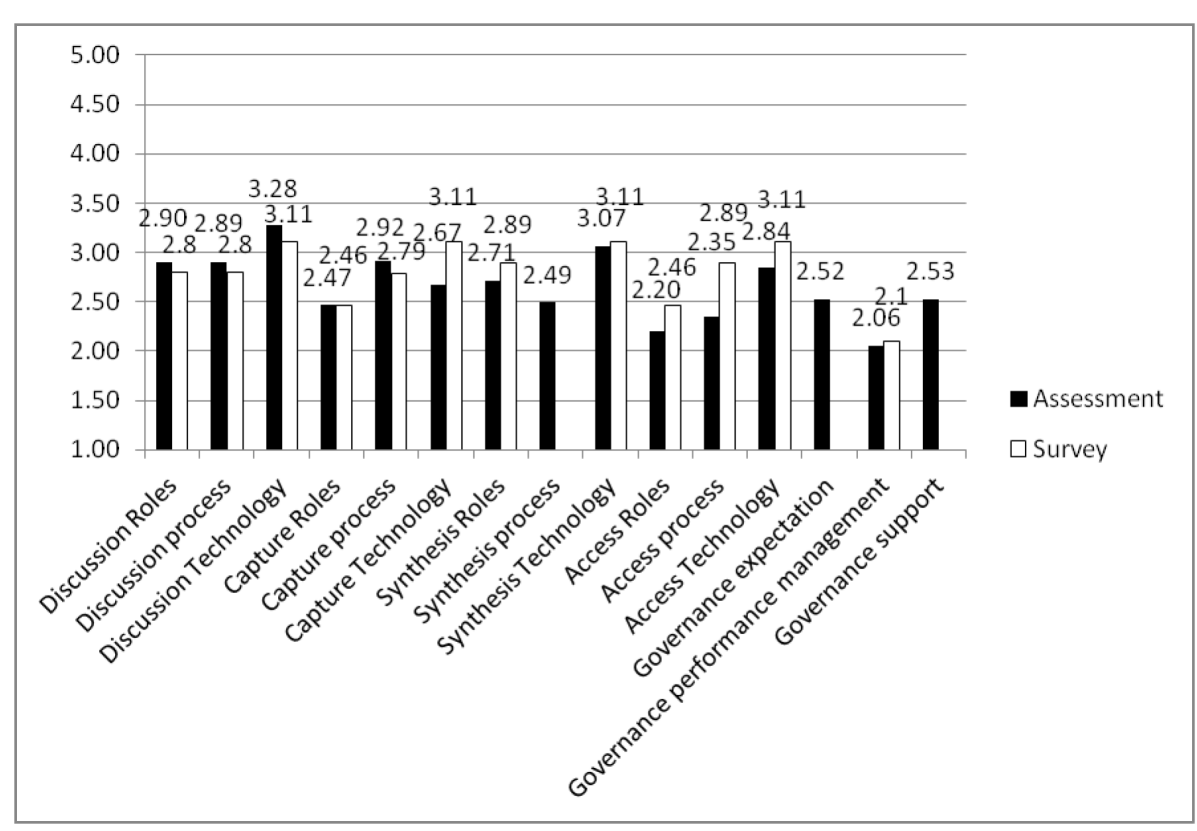

Figure 7. Comparison of the scores from the assessment and survey, for equivalent components

\section{Discussion}

The results from Figure 7 suggest that the Survey and the Assessment are measuring the same things in a similar way, despite very different datagathering methods. Scores are similar, and trends within the scores are similar. This similarity reinforces the assumption that the data are real, and reflect the reality of Knowledge Management initiatives.

The main conclusions to draw from the data at this stage are as follows:

- Firstly, technology is a relative strength in the Knowledge management approaches applied to date(Figures 5 and 2).

- Secondly, the Discussion of Knowledge is a relative strength (Figure 5 ) reflecting the popularity of Communities of Practice, and the availability of Social technologies.

- Thirdly, the greatest weakness in all the data-sets is Knowledge Management Governance - the leadership and support structures that provide the reason and the reward for doing Knowledge Management. This is clear in Figure 2 and Figure 6, and further illuminated in Figure 7, where the lowest scoring, and therefore least effective, element of KM is Performance Management. This element 
represents the way that Knowledge Management is measured and rewarded, and is one of the elements that drive the behaviors and cultures.

- Fourthly, both Figure 6 and Figure 2 point out the weakness of the Knowledge Roles element.

- Fifthly, the weakest of all the Knowledge Management transitions is Knowledge re-use - the transition from documented knowledge to "knowledge in action" - i.e. knowledge in people's heads and consciousness which helps them make the correct decisions.

With more assessments and surveys over time, we might be able to interrogate the data more finely, and speculate on why some effects have been observed.

The correlation between the assessment and the strategy suggest some level of empirical support for the utility of the SECI model of Nonaka and Takeuchi. This model forms one dimension of the Assessment matrix shown as Figure 1, and the independent corroboration of the survey results with the Assessment results suggests that the this model may have utility as a way of analyzing the components of a Knowledge Management Framework.

The strengths and weaknesses identified through the data may be used to infer potential areas for organizations to address as part of Knowledge Management implementation. If companies wish to improve beyond their current maturity level or framework completeness, then acquiring more and better technology should perhaps not be the primary focus, as Technology seems seldom to be the weakest element. There are many other, much weaker elements which will need to be addressed before Knowledge Management will add value.

Governance is a crucial element that seems to be a generic weakness, and without there is no organizational drive towards doing $\mathrm{KM}$, and $\mathrm{KM}$ remains an unmeasured, unrewarded optional component. Similarly without clear roles and accountabilities (another common weakness) nobody is clear what they are supposed to do in Knowledge Management terms, which often results in jobs not getting done, and people waiting for others to take the lead. Finally Knowledge re-use is a common weakness which many organizations may need to address, as any efforts in knowledge capture and synthesis are wasted effort if that knowledge does not get re-used.

The availability of international datasets such as these, collected by practitioners over a number of years, offers a valuable opportunity for research. Research programs to date tend to be case-based; rigorous shortterm in-depth investigations - often survey-based - with the aim of answering specific questions. Consultant practitioners on the other hand collect data on a very long term basis, across multiple organizations, sectors and countries, 
although seldom testing hypotheses from the data with academic rigor. There is surely an opportunity for collaboration between research and practice to make better use of practitioner datasets.

Perhaps the most valuable fruits of this collaboration might lie in the ability to test more systematically some of the models and heuristics being applied by practitioners. Experienced Knowledge Management practitioners "know" what works, but this knowledge is often empirical practical knowledge with no sound basis in theory. Models such as SECl have proven valuable in explaining Knowledge Management, and in developing frameworks such as shown in Figure 1, to categorize and assess Knowledge Management in action. The data presented here provides a cross-check on that framework and seems to support its validity or utility, and further studies would be welcome to provide testing and a theoretic underpinning for practitioner heuristics.

\section{Conclusion}

Data gathering over many years on the strengths and weaknesses of elements of a Knowledge Management framework have allowed these to be aggregated and compared. Technology seems to be the strongest most mature factor in Knowledge Management programs worldwide, and of the four Knowledge Transitions, the strongest is Tacit to Tacit discussion (roughly equivalent to the Socialization element of Nonaka and Takeuchi, 1995). The weakest elements are Governance and Knowledge Management roles, and the weakest of the four Knowledge Transitions is Access and Re-use (roughly equivalent to the Internalization element of Nonaka and Takeuchi, 1995). Datasets such as these suggest a potential avenue for collaboration between practitioners (rich in data, but untrained in academic rigor) and academia (with rigor, but often short of data). 


\title{
References
}

Hofstede, G., Hofstede, G. J., \& Minkov, M. (2010). Cultures and Organizations: Software of the Mind. 3rd Edition. USA. McGraw-Hill.

Nonaka, I. \& Takeuchi, H. (1995). The knowledge-creating company. New York: Oxford University Press.

\begin{abstract}
Abstrakt (in Polish)
Dane zebrane w badaniu internetowym oraz z kilku szczegółowych ocen firm rzucaja nowe światło na relatywne mocne i słabe punkty różnych elementów schematów zarzqdzania wiedzq o globalnym zastosowaniu. Badanie internetowe - szybki test do samodzielnego wypełnienia, pokazuje, że najsilniejszymi elementami schematu sq Technologia, Zachowania i Kultura. Najsłabszymi elementami sq Ład i Role w Zarzq̨dzaniu Wiedzq. Ocena - szczegółowy proces diagnostyczny oparty na dogłębnych wywiadach, pokazuje, że najmocniejszymi składnikami schematu sq Technologia i Dyskusja, zaś najsłabszymi Ład i Role w Zarzqqdzaniu Wiedzq. Porównanie wyników uzyskanych z tych dwóch źródet pokazuje jak bardzo sq one zbliżone. Większa ilość danych może pozwolić nam na dokładniejszq analizę. Wstępne wyniki sugerujq, że kultura narodowa może wpływać na rozwój Schematów Zarzqdzania Wiedzq, może też zachodzić korelacja między silnym Indywidualizmem a słabym Ładem i Rolami w Zarzq̨dzaniu Wiedzq.

Słowa kluczowe: badanie zarzqdzania wiedzq, ocena zarzqdzania wiedzq, wzorcowe zarzq̨dzania wiedzq, schemat zarzq̨dzania wiedzq, role w zarzq̨dzaniu wiedzq, technologia w zarzq̨dzaniu wiedzq, ład w zarzq̨dzaniu wiedzq.
\end{abstract}

\section{Biography}

Dr. Nick Milton is director and co-founder of Knoco Ltd, with 22 years history working in Knowledge Management. Working with Knoco Ltd, Nick has been helped develop and deliver KM strategies, implementation plans and services in a wide range of different organizations around the globe. He has a particular interest in Lessons Learned programs, and has managed major lessons capture programs, particularly in the area of mergers and acquisitions, and high technology engineering. He is the author of "Designing a Successful KM Strategy; a Guide for the Professional Knowledge Manager" (Information Today, in press), "The Lessons Learned handbook" (Woodhead publishing, 2010) and "Knowledge Management for Teams and Projects (Chandos Publishing, 2005), and co-author of "Knowledge Management for Sales and Marketing (Chandos Publishing, 2011) and "Performance through Learning - knowledge management in practice" (Elsevier, 2004). Prior to founding Knoco, Nick spent two years at the centre of the team that made $\mathrm{BP}$ the leading KM company in the world, acting as the team Knowledge Manager, developing and implementing BP's knowledge of "how to manage knowledge", and coordinating the BP KM Community of Practice. Nick blogs 
most days (www.nickmilton.com) and can be found on Twitter (@nickknoco). Director, Knoco Itd. Rose Cottage, Burnett, Keynsham, Bristol, UK BS31 2TE. +44 7803 592947. Email: nick.milton@knoco.com. 
